called the marine branch of hydrodynamics are of such great value, has stated that "he has never noticed a wave so much as Ioft. high in Ioft. water, nor so much as $20 \mathrm{ft}$. high in 20 ft. water, nor 3 oft. high in five fathoms water; but he has seen waves approach very nearly to those limits." $\mathrm{Mr}$. Russell has not stated whether the depths of water referred to are those below the trough of the sea or below the still-water level. In my book on "Harbours" I gave three observations on short waves from $2 \mathrm{ft}$. $6 \mathrm{in}$. to $3 \mathrm{ft}$. high, which corroborated Mr. Russell's statement, supposing him to refer to the depth below the hollow. But since that time I had an opportunity, during a N.E. swell in July 1870, of observing the depths in which waves of a larger class broke at the Promenade Pier at Scarborough, where the heights could be measured with very considerable accuracy on the iron piles and open sloping slip or grating at the seaward end of the pier; and the following are the results :-

Heights of waves from hollow to crest.

$$
\begin{array}{ll}
5 & 6 \\
5 & 0 \\
5 & 0 \\
5 & 6 \\
\hline 5 & 3
\end{array}=\text { mean height. }
$$

The mean depth of water below the trough was roft. 3 in.

Heights of the highest waves from hollow to crest.

$$
\begin{array}{ll}
6 & 0 \\
6 & 0 \\
8 & 0 \\
6 & 0 \\
6 & 0 \\
\hline 6 & 6
\end{array}
$$

The mean depth of water below the trough was $13 \mathrm{ft} .8 \frac{1}{2} \mathrm{in}$. So that in both cases those waves did not follow Mr. Russell's law, but broke when the depths below their tronghs were about twice iheir own height.

It must not be supposed, as is generally believed, that the height of the crest above the mean level of the sea is equal to the depression of the trough below that level; for Prof. Rankine has lately shown that this is not the case. When $L=$ length of wave, $H=$ height from trough to crest.

$$
\begin{aligned}
& \text { Crest above still water }=\frac{H}{2}+7854 \frac{H^{2}}{L} . \\
& \text { Trough below still water }=\frac{H}{2}-7854 \frac{H^{2}}{L} .
\end{aligned}
$$

These formulæ, he states, are exact only for water of considerable depth as compared with the wave's length. Edinburgh

THOMAS STEVENSON

\section{CYCLONES IN THE INDIAN OCEAN}

SEVERAL cyclones have passed Mauritius since the latter part of January. From the 24 th to the 3oth of that month the barometer at the Observatory fell from 29.888 to 29708 inches, with the wind squally from E. At IO A.M. on the 3 oth it was intimated to the newspapers that there were "indications of a hurricane approaching the island;" but at 2 P.M., the wind having in the interval veered to $\mathrm{N}$. of $\mathrm{E}$, it was announced that there was "little danger."

This storm was encountered by the schooner Emily, on her passage from Tamatave, from Jan. 29 to Feb. I. At the commencement of the gale, she was in $19^{\circ} 3 \mathrm{I}^{\prime} \mathrm{S}$., and $53^{\circ} 30^{\prime} \mathrm{E}$. The wind veered from N.E. to E., S.E., S., S.W., W., and N.W., with a "tremendous sea and torrents of rain," and the lowest reading of the barometer on board was $29^{\circ} 00$ inches. The vessel escaped with the loss of only a few sails.

The storm then curved to the $\mathrm{S}$. and $\mathrm{E}$, and was experienced by the barques Gladiateur and Abbotsford on Feb. 2 and 3 , in $31^{\circ}$ to $29^{\circ} \mathrm{S}$, and $54^{\circ}$ to $55^{\circ} \mathrm{E}$. With the former vessel the wind veered from E. to N.E. and N., blowing at one time with great violence. The barometer at. 8 A.M. on the 2nd was at 28.80 , and the wind from E.N.E. The Abbotsford had the wind from the same direction, and her barometer was at 28.40 at 5 A.M. on the 2nd. Both vessels had a "tremendous sea and torrents of rain," and they lost sails and bulwarks.

On Feb. 5 the barometer at Mauritius, after rising to $29^{\circ} 790$, again began to fall, and on the 7 th was at $29^{\circ} 606$. The wind was squally from S.E., and it veered to S. by W., from which point there was a gentle breeze at $9.3^{\circ}$ P.M. on the 7 th, with fine clear weather.

At Io A.M. on the 7th it was announced that "the weather of the last two or three days indicated the passage of another storm, which then broke between E.N.E. and E. ;" and at Io A.M. on the following day that "the storm had curved to the S. and S.E."

This storm was encountered by the barque Elizabeth, from Melbourne to Mauritius, on the 7 th and 8th, in $20^{\circ} \mathrm{I} 6^{\prime} \mathrm{S}$., and $68^{\circ} \mathrm{E}$. The wind was strongest from E.N.E. to N.N.E., and the lowest barometer was $29^{\circ} 20$. There were "torrents of rain." By standing back to the E. the Elizabeth avoided all danger.

On Sunday, Feb. II, the barometer at the Observatory, after rising to $29^{\circ} 80$, again began to fall, with the wind squally from S.E., and the weather fine. During the 12 th it fell 060 inch, and 090 inch more during the 13 th, with the wind still squally from the same quarter. At Io A.M. on the i4th the following notice was sent to the newspapers:- "A hurricane since the IIth. It now bears about E.N.E. of us. There are some signs that it will pass to the $E$. and $S$. of the island, but there is dang€r." The barometer still falling, and the wind increasing to strong breezes from S. by E. to S.S.E, at 3 P.M. a telegram was sent to Port Louis (6 miles off), stating that "the centre of the hurricane was about 350 miles to the E.N.E., and approaching the island," and soon afterwards storm signals were hoisted at the railway stations. The barometer at 3 P.M. stood at $29^{\circ} 6 \mathrm{I} 2$, and the wind, which was then S. by E., was blowing with an estimated force of $2.5 \mathrm{lbs}$. on the square foot.

At 9 A.M. on the 15 th the barometer was at $29^{\circ} 478$, with a strong gale from S.E., and it was estimated and announced that the "centre of the storm bore about N.N.E. 150 to 200 miles, and that it was still approaching the island." At 3 P.M. the wind being from E.S.E. to E. by $\mathrm{S}$. in increasing gales, and the barometer at 29382 , it was telegraphed to Port Louis that "the centre was about I 50 miles to N. by $E$., and that it would probably pass, with an increase of wind, to N.W. and W. of the island, without doing much damage."

During the night the wind increased considerably from E.S.E. to E. by S., and the barometer attained its lowest reading $\left(29^{\circ} 328\right)$ at I A.M. on the I6th ; but the mercury was oscillating, being at 2 A.M. at $29^{\circ} 35^{6}$, and at 3 A.M. $29^{\prime} 330$; and the time of the greatest depression of the mercury, as shown by the barograph (at the Magnetic Observatory, three miles off) was 2.40 A.M. At 9 A.M. the barometer was at $29^{\circ} 440$, with the wind at E. to E. by N., and it was announced that "the centre bore N.N.W., and that there was no danger."

The barometer then continued to rise, until, at noon on the 18 th, it was at 29.882 , with a moderate breeze from N.E.

It is worthy of remark that the wind never went beyond N.N.E., but gradually backed to East.

This storm was more or less encountered at sea by the Harpesia, Gryfe, Oleander, St. Germaine, Misser, $S . S$. 
Danube, Staffordshire, Willian Fairbaim, Pendragon, Odalisk, and Paolo Revello, some of which suffered severely.

At 5 A.M. on the I5th, the Staffordshire, in about $18^{\circ} 30^{\prime} \mathrm{S}$. and $61^{\circ} \mathrm{E}$., was thrown on her beam ends, and in great danger of foundering. The William Fairbaim, a fine iron vessel of 1,293 tons, lost all her masts and sails, and had her decks almost completely swept. On the I 3 th, in $19^{\circ} 2^{\prime} \mathrm{S}$., and $64^{\circ} 4 \mathrm{O}^{\prime} \mathrm{E}$., she had a strong gale from S.E., which increased to a hurricane. About 7 P.M. her barometer was at 2870 , and early on the I4th the wind shifted from S.E. to N.W. The Paolo Revello, on the 14 th, in $18^{\circ} 8^{\prime} \mathrm{S}$. and $61^{\circ} 54^{\prime} \mathrm{E}$., was completely gutted. The captain's papers and log-book, cabin furniture, $\& c$. , together with the chief officer and nine men, were washed overboard.

From the logs hitherto received it appears that the storm was formed between the S.E. trade-winds, and the N.W. monsoon from the 7 th to the gth. On the roth the centre was in $13^{\circ} 10^{\prime} \mathrm{S}$. and $78^{\circ} 30^{\prime} \mathrm{E}$; ; on the 12 th in $15^{\circ} 6^{\prime} \mathrm{S}$., and $71^{\circ} 34^{\prime} \mathrm{E}$; ; on the 14 th in $17^{\circ} 15^{\prime} \mathrm{S}$., and $63^{\circ} 28^{\prime} \mathrm{E}$.; on the 16 th in $20^{\circ} 7^{\prime} \mathrm{S}$., and $55^{\circ} 50^{\prime} \mathrm{E}$.; and on the I8th in $22^{\circ} 15^{\prime} \mathrm{S}$. and $51^{\circ} 50^{\prime} \mathrm{E}$. During the first six days it travelled on a W.S.W. course, and then curved a little towards the south. It passed about 165 miles north of Rodrigues at noon on the I4th, about 65 miles north of Mauritius early on the 16 th, and N.N.W., \&c., of Reunion from noon on the I6th to noon on the I7th. Its average rate of progression was nine miles an hour, and the area over which the wind blew from strong breezes to hurricane violence was about 800 miles.

The fact that in this, as in other storms, the wind at Mauritius did not veer more than twelve points, seems to be explained by the incurving of the air towards the centre.

On the evening of the 15 th, or morning of the 16 th, seventeen vessels put to sea from the roadsteads of Reunion, and their fate is not yet known. If they held to the N.W., with the wind from S.E., they probably got into the heart of the storm.

\section{Mauritius, March 8}

\section{Charles MeldRUM}

P.S.- The aurora seen here on the night of the 4 th to 5 th February, was also seen at sea by several vessels. Here are extracts from their logs :-

Olive Branch in $27^{\circ} 47^{\prime} \mathrm{S}$. and $59^{\circ} 48^{\prime}$ E.- "At Io P.M. the sky became very red and fiery-southern lights."

Abbotsford in $30^{\circ} 9^{\prime} \mathrm{S}$. and $56^{\circ} \mathrm{Io}^{\prime} \mathrm{E}$.- "Dull atmosphere. Aurora australis reflecting brightly in the south, giving light over all the ship. Clouds tinged with deep red."

Elizabeth in $20^{\circ} 33^{\prime} \mathrm{S}$. and $78^{\circ} 3^{\prime}$ E.- "At 10 P.M. Aurora australis unusually bright."

Gladiateur in $30^{\circ} 32^{\prime} \mathrm{S}$. and $57^{\circ} 28^{\prime}$ E.-. "At 8 P.M. a red and yellow and strange looking sky. Midnight, sky the same."

Pendragon in $13^{\circ} 43^{\prime} \mathrm{S}$. and $84^{\circ} 13^{\prime} \mathrm{E}$.- " At midnight very suspicious-looking weather to the $S$., the sky being quite red."

William Fairbairn in $32^{\circ} 57^{\prime} \mathrm{S}$. and $60^{\circ} 2^{\prime}$ E.-." At ro P.M. looking ugly, and meteorological signs of a hurricane. Midnight same, and up till 3 A.M. when it cleared off."

Caton in $3 \mathrm{I}^{\circ} 3 \mathrm{I}^{\prime} \mathrm{S}$. and $108^{\circ} 1 \mathrm{O}^{\prime} \mathrm{E}$-.."Midnight, red sky, like fire to E.S.E."

Oleander in $38^{\circ} 26^{\prime} \mathrm{S}$. and $31^{\circ} 53^{\prime} \mathrm{E}$ - "From 7.30 to II.3O P.M. the sky was illuminated with a very brilliant Aurora australis."

There is little doubt that the suspicious-looking weather to the S., seen by the Pendragon in about $14^{\circ} \mathrm{S}$., was the aurora. Captain McKenzie of the W. Fairbairn reports that his standard compass was affected to the extent of $\frac{3}{4}$ of a point, and his other compass to the extent of two to three points.

\section{PHYSICAL SCIENCE IN GLASGOW UNIVERSITY}

$7 \mathrm{HE}$ Physical Laboratory of Glasgow University, which till quite lately was the only one in this country, dates from the year 1852 . It was with difficulty that room could be found for a laboratory of any kind in the old building; but in the new building, of which this is the second year of habitation, considerable space has been set apart for Experimental Natural Philosophy.

At present six rooms belong to the department, exclusive of the Professor's private sitting-room and the store-rooms, and on the completion of the tower, which is not yet finished, additional rooms will be devoted to it. The whole suite of rooms is arranged so as to be in di. rect communication with those of the professors of mathematics, engineering, and astronomy.

The chief lecture-room is $42 \mathrm{ft}$. long by $35 \mathrm{ft}$. broad, its side windows look nearly north and south, and over the lecture table there is a glass-covered turret, or louvre, the top of which is 4 oft. from the floor. The windows of the room are completely darkened with the greatest ease by means of double curtains of blue baize, an inner and an outer curtain for each window, and these can be unfurled and furled at a moment's notice; two baize screens, one below the other, are drawn across the base of the louvre. The room is ventilated, as are all the rooms in the new Uni. versity building, on Mr. Phipson's plan. Pure air is drawn down a shaft in the tower by fanners, which are worked by a small steam engine. The air is passed through a dry chamber, containing hot water pipes, and is then driven mixed with any quantity of fresh cold air that may be required, into the class-room. It enters at the top of the room, and the used air is drawn off through passages below the floor.

Benches are arranged for about I50 students. They are not on a level, but rise at an angle of $25^{\circ}$, and beneath them there is a large convenient space, with shelves for 50 or more cells of Daniell's battery, which I shall describe immediately.

Of the other five rooms one is an additional lecture and experiment room, one is the general laboratory, one is the principal apparatus room and museum, and the remaining two are used for storing apparatus and for occasional experimenting. The laboratory is on the ground floor, and is below the lecture-room, which is on the second story. It is a room $52 \frac{1}{2} \mathrm{ft}$. long by $34 \mathrm{ft}$. broad. It has six windows, three looking north and three looking south, and these can be darkened like those in the lecture-room by means of drop curtains of baize. Three quarters of the floor is wood, the remainder concrete, covered with Portland cement; but in order to get perfectly steady tables, piers of masonry, built on the foundation, rise through the floor, and on them the feet of the tables rest. The flooring does not touch the piers at all, and thus, however much the floor may shake, the table remains comparatively steady. This arrangement gives far greater steadiness than a complete stone floor. Besides these piers there are two somewhat larger stone constructions, which are also unconnected with the flooring; one of these is intended for a large steady table; and on the other there is a massive stone erection (Fig.I), on which is to hang a pendulum for a clock, or for experiments on the force of gravity. It is intended that the point of suspension of the pendulum shall be perfectly free from vibration.

Some of the tables are ordinary working tables. On others, instruments such as the electrometer and electrodynamometer are set. Below the table there are frames for supporting 500 cells of a constant Daniell's battery, which were in use in the old college, and a great part of which are now re-charged.

In one corner of the room there is a wooden enclosure, which is fitted up as a small chemical bench. The ordinary reagents and apparatus for chemical testing are thus at hand. 